DOI: https://doi.org/10.15407/techned2018.05 $: \underline{096}$

\title{
APPLICATION OF GSM TECHNOLOGY FOR IDENTIFICATION OF PHASE-TO-GROUND FAULTS IN ELECTRIC NETWORKS WITH ISOLATED NEUTRAL AND PIN-TYPE ISOLATION
}

Journal

Publisher

ISSN

Issue

Pages
Tekhnichna elektrodynamika Institute of Electrodynamics National Academy of Science of Ukraine 1607-7970 (print), 2218-1903 (online)

No 5, 2018 (September/October)

$96-99$

\section{Authors}

V.M. Bezruchko ${ }^{1 *}$, R.O. Buinyi ${ }^{1 * *}$, A.Y. Strogii ${ }^{1}$, V.I. Tkach ${ }^{2}$

1 - Chernihiv National University of Technology, str. Shevchenka, 95, Chernihiv, 14035, Ukraine,

e-mail: slavajm@meta.ua, buinyiroman@gmail.com

2 - PJSC Chernihivoblenergo, str. Goncha, 40, Chernihiv, 14000, Ukraine

* ORCID ID : http://orcid.org/0000-0002-3705-8543

** ORCID ID : http://orcid.org/0000-0002-5432-2924

A method for identifying single-phase-to-ground faults through pin isolation in networks with isolated neutral is proposed. It involves installation of devices on each tower of overhead power line. Those devices will be powered by the current of the single phase-to-ground faults. When the short-circuit current flows through the grounding step-down of the tower, the device sends a signal trough a GSM network to the control center. It is shown that such devices can be powered even by the minimum values of the fault current, that is why there is no need in further short-circuiting to find the localization of the fault. Estimated the minimum required capacity of the energy accumulator for reliable transmission of the signal through the GSM network. Refere nces 5 , figures 5 . 
Key words: electric network, isolated neutral, single phase-to-ground faults, search for a fault location, identification method.

Received: 02.03 .2018

Accepted: 04.04 .2018

Published: 16.08 .2018

\section{References}

1. Buinyi R., Dikhtyaruk I., Zorin V. The automatic sectionalization of the distributing networks with high voltage of $610 \mathrm{kV}$ with application the disconnectors of new generation. Tekhnichna Elektrodynamika

. 2014. No 3. Pp. 70-75. (Ukr)

2. Kucheryavenkov A.A., Karpashev A.S. Device for determining the location and type of damage to the overhead power line. Patent for utility model Russia No 126144, 2013. (Rus) 3. Cheremisin M.M., Zubko V.M., Korobka V.O., Sidorov H.A., Pyrozhenko A.A. Short-circuit lock. Patent Ukraine No 64352 A, 2004. (Ukr)

4. Zubko V.M., Korobka V.O., Miroshnyk O.V. Effectiveness of monitoring of closures in the degree of horror with isolated neutral. Visnyk Kharkivskoho natsionalnoho tekhnichnoho universytetu silskoho hospodarstva im. Petra Vasylenka

2010. No 102. Pp. 21-23. (Ukr)

5. Manual. Kit of short-circuit indicators IRZ-B33-U3. URL: http://www.antraks.ru/biblioteca/no rmativnaya-dokumentatsiya?download=104:komplekt-indikatorov-korotkogo-zamykaniya-ikz-v3 $\underline{3-43}$

(Accessed 10.02.2018).

(Rus) 


\section{PDF}

